\title{
Regional allocation methodology for agricultural support
}

\author{
Denis Samygin ${ }^{1, *}$, Nikolaj Baryshnikov ${ }^{2}$, Sergey Imyarekov $^{3}$, and Lyudmila Ponimatkina ${ }^{4}$ \\ ${ }^{1}$ Penza State University, Penza, Russian Federation \\ ${ }^{2}$ Penza State Agrarian University, Penza, Russian Federation \\ ${ }^{3}$ Russian University of Cooperation, Mytishchi, Moscow region, Russian Federation \\ ${ }^{4}$ Financial University under the Government of the Russian Federation, Moscow, Russian Federation
}

\begin{abstract}
The problem of the methodology of quota allocation for agricultural support to regions is raised. It is shown that the problem is related to the selection of criteria and applied key figures for distribution. It has been proved that the share of regions in production and economic results in agriculture does not indicate the efficiency of economic activity and the effective impact of state support on this. Current scientific studies on this problem have been summarized and model calculations have been carried out using econometric analysis tools. It has been established that the largest dependence on agricultural support is observed in the volume of gross production, profit from sale and the level of profitability. It is justified that these indicators should be used in the methodology of allocation of budgetary funds to the regions in order to create conditions for formation of food independence, improvement of production efficiency, ensuring reproduction of resources. It is argued that this approach will increase the impact of subsidies in regions with different levels of agricultural development.
\end{abstract}

\section{Introduction}

In recent years, the allocation of federal subsidies to regions to support agriculture has been an urgent issue. Today, it is proposed to link the allocation of funds to the regions with the results of the activities of producers. For this purpose, a new support measure, called a "single subsidy," is being implemented. The main reason for finding new approaches to budget allocations is the problems of achieving the projections. According to the Ministry of Agriculture, 78 subjects of the Russian Federation were unable to provide the planned results of agricultural production. The performance indicators of the grants have not been achieved. This is contrary to the principles of the Budget Code of the Russian Federation on the Efficiency of Use of Public Funds. Therefore, the Government proposes new rules that create conditions for improving the validity of the indicators of regional agricultural development programmes.

\section{Review of literature}

Since the economic transformation in our country, there have been sharp discussions on the principles of allocation of budgetary transfers to budget recipients in the agricultural sector. These disputes have become increasingly scientific in recent years.

Among scientists, the most common idea is to improve the efficiency of the distribution of public subsidies through the algorithm of optimizing the costs of supporting agriculture $[1,2]$. It is proposed to improve measures of state support of producers, increase incentives to achieve forecasts [3, 4]. Rational allocation of government support through investment security indicators is proposed [5]. The method of allocation of support funds based on regression coefficients in the economic and mathematical model of agricultural development is justified [6].

In the western countries the operating principles of distribution of subsidies lead to the fact that from 35 to $75 \%$ of state support are received by $25 \%$ of large-scale enterprises which produce from 45 to $85 \%$ of all gross output of agricultural industry, making it from 50 to $75 \%$ of income of farmers. Small are farms more depend on payments, which they receive as they make the most part of gross revenue. In the majority of the countries, the state support is directed to reduction of a difference in income between farms owing to the fact that lowprofitable enterprises often get more supports [7].

In Russia, more scientists are leaning towards a differentiated approach to the allocation of agricultural financing [8]. In scientific research, an index assessment of the resource base of enterprises is used. It allows to take into account different conditions of management and to differentiate the volume of state support [9]. It is proposed to take into account the bioclimatic potential of the regions in the allocation of subsidies for crop production support [10]. Methodological approaches to determining sectoral specialization of agro-industrial production are being formed. Allocation of budget funds is based on consideration of natural and climatic diversity of rural areas [11]. It is proposed to take into account the agrarian potential of the regions and to

* Corresponding author: vekont82@ mail.ru 
determine the impact of the use of budgetary resources in different natural conditions of reproduction [12].

\section{Methodology}

Modern procedure for allocation of tranches from the federal budget to regions for support of agriculture is based on a system of indicators, among which the share of the subject of the Russian Federation.

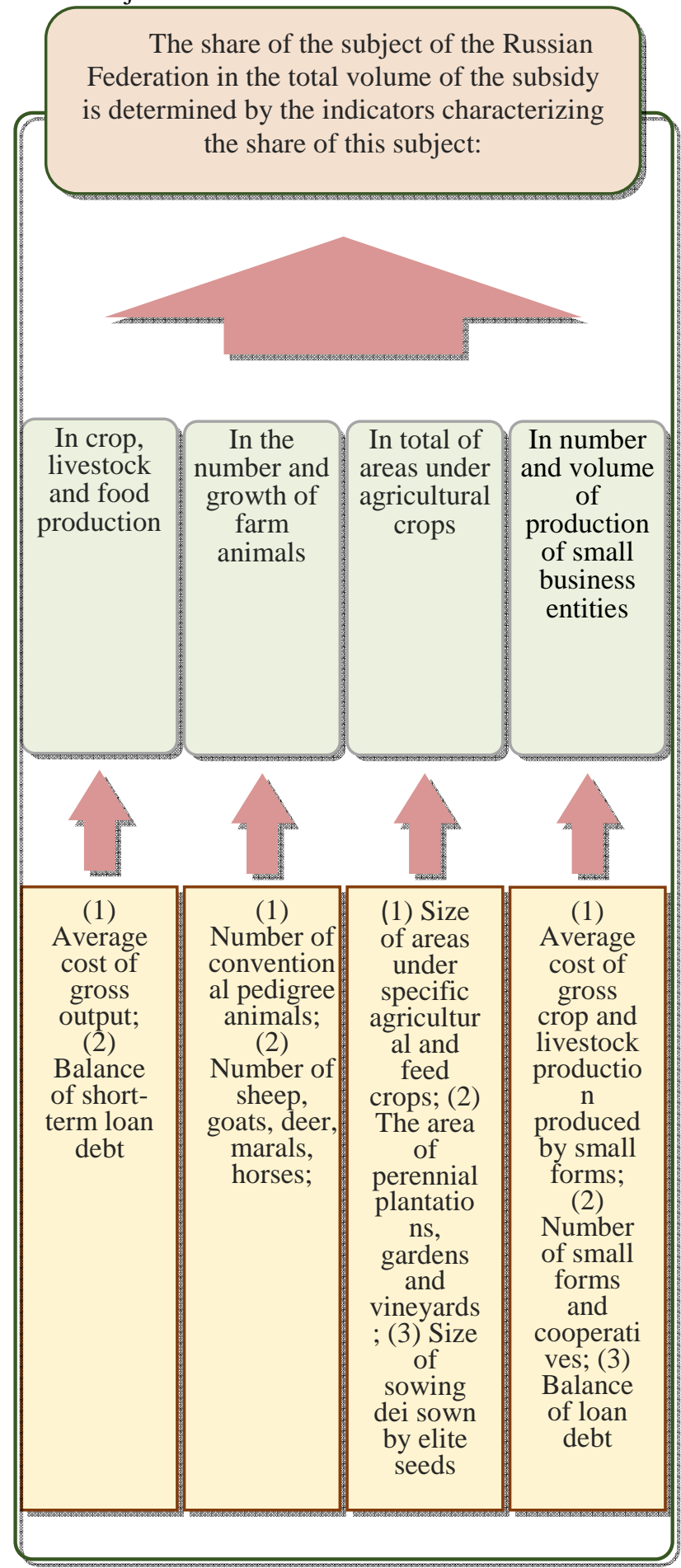

Fig. 1. Criteria for the allocation of subsidies to regions for agricultural support

The official technique of distribution of federal subsidies is based criteria of specific weight of the

region in the cost of gross output, in the number of a livestock of agricultural animals, in the sum of the areas under crops, in the number of farms (table 1).

Table 1. Distribution technique federal subsidies to regions.

\begin{tabular}{|c|c|}
\hline Indicator & Assessment algorithm \\
\hline $\begin{array}{c}\text { Region } \\
\text { share in the } \\
\text { gross } \\
\text { production } \\
\text { volume (V)i }\end{array}$ & $\begin{array}{c}\mathrm{V}_{\mathrm{i}}=\frac{\mathrm{D}_{\mathrm{ii}} \times 0,8+\mathrm{D}_{2 \mathrm{i}} \times 0,2}{\sum_{\mathrm{i}=1}^{\mathrm{n}}\left(\mathrm{D}_{1 \mathrm{i}} \times 0,8+\mathrm{D}_{2 \mathrm{i}} \times 0,2\right)} \\
\mathrm{D}_{1 \mathrm{i}} \text { is the region's share in the average cost of } \\
\text { gross output; }\end{array}$ \\
$\begin{array}{c}\mathrm{D}_{2 \mathrm{i}} \text { is the region's share in the remains of loan } \\
\text { debt on the short-term credits }\end{array}$ \\
$\begin{array}{c}\text { Region } \\
\text { share in } \\
\text { number and }\end{array}$ & $\mathrm{P}_{\mathrm{i}}=\frac{\mathrm{D}_{3 \mathrm{i}} \times 0,45+\mathrm{D}_{4 \mathrm{i}} \times 0,15+\mathrm{D}_{5 \mathrm{i}} \times 0,4}{\sum_{\mathrm{i}=1}^{\mathrm{n}}\left(\mathrm{D}_{3 \mathrm{i}} \times 0,45+\mathrm{D}_{4 \mathrm{i}} \times 0,15+\mathrm{D}_{5 \mathrm{i}} \times 0,4\right)}$ \\
\hline
\end{tabular}

gain of a

livestock of

farm

animals $(\mathrm{P}) \mathrm{i}$

conditional uterine breeding livestock of farm animals;

$\mathrm{D}_{4 \mathrm{i}}$ is the region's share in the number of a uterine livestock of sheep and goats, livestock of reindeers, marals and meat tabunny horses; $\mathrm{D}_{5 \mathrm{i}}$ is the region's share in gain of number of a commodity livestock of cows of specialized meat breeds

Region

share of the areas under crops (S)i

$S_{i}=\frac{D_{6 i} \times 0,24+D_{7 i} \times 0,07+D_{8 i} \times 0,37+D_{9 i} \times 0,32}{\sum\left(D_{6} \times 0,24+D_{1} \times 0,07+D_{8} \times 0,37+D_{9} \times 0,32\right)}$
$\sum_{\mathrm{i}=1}^{\mathrm{n}}\left(\mathrm{D}_{6 \mathrm{i}} \times 0,24+\mathrm{D}_{7 \mathrm{i}} \times 0,07+\mathrm{D}_{8 \mathrm{i}} \times 0,37+\mathrm{D}_{9 \mathrm{i}} \times 0,32\right)$

$\mathrm{D}_{6 \mathrm{i}}$ is the region's share in the area sowed by elite seeds;

$\mathrm{D}_{7 \mathrm{i}}$ is the region's share in the area of a lowproductive arable land (black fallow) and cultivated area of forage crops in the region of the Far North and the areas equated to them;

$\mathrm{D}_{8 \mathrm{i}}$ is the region's share in the area of longterm plantings;

$\mathrm{D}_{9 \mathrm{i}}$ is the region's share in the area of vineyards.

Region

share in number of peasant farms $(\mathrm{K}) \mathrm{i}$

The size of the subsidy provided to the region on

assistance to achievement of target indicators of regional programs (W)i

$$
\mathrm{K}_{\mathrm{i}}=\frac{\mathrm{D}_{10 \mathrm{i}} \times 0,3+\mathrm{D}_{11 \mathrm{i}} \times 0,5+\mathrm{D}_{12 \mathrm{i}} \times 0,2}{\sum_{\mathrm{i}=1}^{\mathrm{n}}\left(\mathrm{D}_{10 \mathrm{i}} \times 0,3+\mathrm{D}_{11 \mathrm{i}} \times 0,5+\mathrm{D}_{12 \mathrm{i}} \times 0,2\right)}
$$

$\mathrm{D}_{10 \mathrm{i}}$ is the region's share in number of peasant farms, individual entrepreneurs and agricultural consumer cooperatives;

$\mathrm{D}_{11 \mathrm{i}}$ is the region's share in the average cost of the gross output of crop production and livestock production made by peasant farms and individual entrepreneurs;

$\mathrm{D}_{12 \mathrm{i}}$ is the region's share in the rest of loan debt on the credits taken by small farms

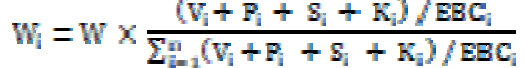

$\mathrm{EBC}_{\mathrm{i}}$ is the level of estimated fiscal capacity of the region the current financial year calculated according to a technique of distribution of grants for alignment of fiscal capacity of territorial subjects of the Russian Federation

$\mathrm{n}$ is the number of the territorial subjects of the Russian Federation complying with the conditions of granting and expenditure of subsidies

The analytics of this approach allows concluding that the indicators included in a technique often duplicate each other. So the share of gross output of agricultural industry of the region depends, first, on a share of gross 
output of crop production in the region which is defined by an area share under crops. Second, it depends on a share of gross output of livestock production in the region which is defined by a share of number and gain of a livestock of agricultural animals. Third, it depends on a share of the gross output in the region made by small farms. In fact, the first indicator already includes other three indicators of the technique. That will have a cumulative influence and effect of distortion of distribution of subsidies. We investigate these indicators in more detail regarding their practical approbation.

\section{Results and Discussion}

With use of the specified technique tools in combination with econometric methods we will carry out the analysis and sorting of federal districts according to their share of gross output (table 2). The regularity of such approach is that increase in investments has to be followed by increase in effect.

Table 2. The analysis of federal districts on a share of gross output.

\begin{tabular}{|c|c|c|c|c|c|}
\hline 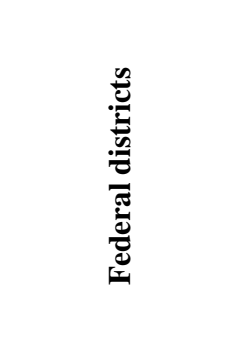 & 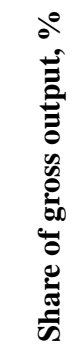 & 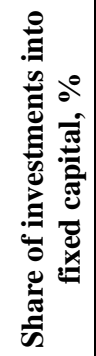 & 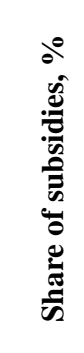 & 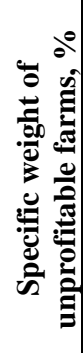 & 离 \\
\hline Far East & 3.01 & 1.94 & 4.80 & 25.9 & 9.80 \\
\hline Northwest & 4.67 & 9.79 & 8.01 & 36.0 & -4.40 \\
\hline Ural & 6.41 & 6.64 & 7.35 & 26.8 & 5.00 \\
\hline North Caucasian & 8.13 & 3.59 & 3.41 & 17.8 & 12.60 \\
\hline Siberian & 13.63 & 8.58 & 10.84 & 18.9 & 9.90 \\
\hline Youzhny & 15.40 & 9.11 & 7.20 & 17.0 & 9.90 \\
\hline Volga & 23.90 & 20.42 & 25.93 & 18.8 & 7.10 \\
\hline Central & 24.84 & 39.71 & 32.45 & 29.5 & 7.50 \\
\hline
\end{tabular}

As well as it was supposed, the regions having a big share of gross output obviously differ in a bigger share of investments into fixed capital, they receive the bulk of budget support.

At the same time, during the growth of a share of investments and a share of gross output in a section of regions, there is no trend for growth of an indicator of profitability and decrease in specific weight of unprofitable farms. Obviously, expenses and effect, especially in agricultural industry, not always harmonize with efficiency.

Using the algorithm of a technique considered above we will carry out the analysis and sorting of federal districts according to a share of a livestock of agricultural animals (table 3 ).
Table 3. The analysis of federal districts on a share of a livestock of agricultural animals.

\begin{tabular}{|c|c|c|c|c|c|c|c|}
\hline \multirow[b]{2}{*}{$\begin{array}{l}\text { Federal } \\
\text { districts }\end{array}$} & \multirow{2}{*}{ 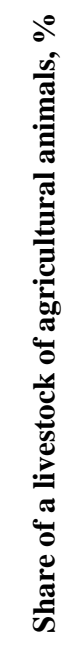 } & \multicolumn{2}{|c|}{ 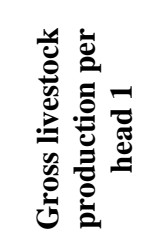 } & \multicolumn{2}{|c|}{ 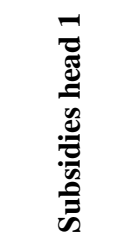 } & \multicolumn{2}{|c|}{ D্ } \\
\hline & & 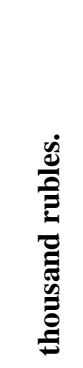 & 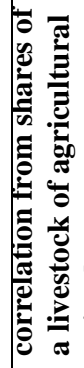 & 它 & 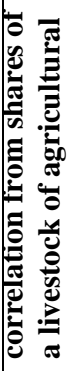 & 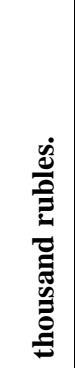 & 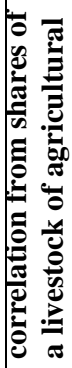 \\
\hline Far East & 2.14 & $\begin{array}{c}157.7 \\
5\end{array}$ & \multirow{8}{*}{$\frac{1}{0}$} & $\begin{array}{c}20 . \\
3\end{array}$ & \multirow{8}{*}{$\stackrel{0}{0}$} & 2.2 & \multirow{8}{*}{$\begin{array}{l}5 \\
0 \\
0 \\
1\end{array}$} \\
\hline Northwest & 3.48 & $\begin{array}{c}231.5 \\
3 \\
\end{array}$ & & $\begin{array}{c}20 . \\
8 \\
\end{array}$ & & $-\overline{6}$ & \\
\hline Ural & 5.34 & $\begin{array}{c}180.5 \\
4 \\
\end{array}$ & & $\begin{array}{c}2 . \\
4 \\
\end{array}$ & & 0.8 & \\
\hline North Caucasian & $\begin{array}{c}11.7 \\
9\end{array}$ & 83.03 & & 2.6 & & 4.0 & \\
\hline Youzhny & $\begin{array}{c}12.4 \\
8\end{array}$ & $\begin{array}{c}116.6 \\
4\end{array}$ & & 5.2 & & 7.5 & \\
\hline Central & $\begin{array}{c}14.4 \\
9\end{array}$ & $\begin{array}{c}218.2 \\
3\end{array}$ & & $\begin{array}{c}20 . \\
2\end{array}$ & & $\begin{array}{c}12 . \\
7\end{array}$ & \\
\hline Siberian & $\begin{array}{c}21.3 \\
2\end{array}$ & 82.34 & & 4.6 & & $\begin{array}{c}- \\
0.3\end{array}$ & \\
\hline Volga & $\begin{array}{c}28.9 \\
5\end{array}$ & $\begin{array}{c}106.8 \\
3\end{array}$ & & 8.1 & & 3.7 & \\
\hline
\end{tabular}

Increase in the numbers of agricultural animals does not lead to an increase in gross output and profit per head. The profitability trend in this case also goes to a section with a livestock share trend. It proves, the statement which is put forward earlier that growth of indicators of a share of production parameters of the region does not demonstrate growth of effectiveness of economic activity yet.

Moreover, this conclusion is confirmed by econometric estimates where the share of a livestock of agricultural animals does not correlate with the called indicators. Quite good communication (0.76) is observed between indicators of gross output and subsidies counting on one head of agricultural animals, however this principle of distribution is not included in a technique.

Applying the technique considered above estimates we will carry out the analysis and sorting of federal districts according to a share of farmlands (table 4).

Comparison of a share of farmlands in a section federal districts shows that its growth is not followed by growth of gross output, subsidies and profits per unit of farmlands, increase in profitability. Correlation communication at the majority of indicators weak also has the return nature of influence. Rather quite good correlation (67\%) between gross output and subsidies is traced, which, however, is also not considered by the official technique. 
The considered elements allow giving an assessment of federal districts for a share of small farms in the agrarian sector (table 5).

Table 4. The analysis of federal districts on a share of farmlands.

\begin{tabular}{|c|c|c|c|c|c|c|c|}
\hline \multirow{2}{*}{$\begin{array}{l}\text { Federal } \\
\text { districts }\end{array}$} & \multirow{2}{*}{ 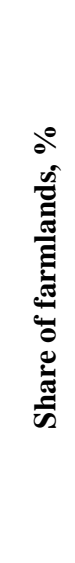 } & \multicolumn{2}{|c|}{ 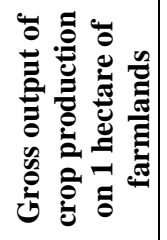 } & \multicolumn{2}{|c|}{ 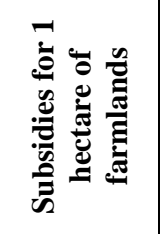 } & \multicolumn{2}{|c|}{ 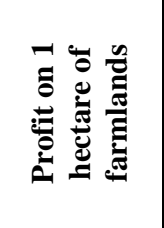 } \\
\hline & & 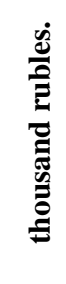 & 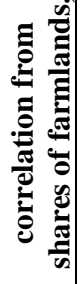 & 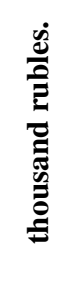 & 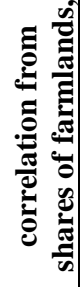 & 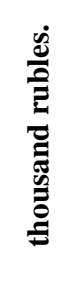 & 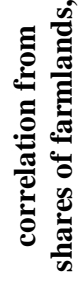 \\
\hline Far East & 2.47 & $\begin{array}{l}23 . \\
31\end{array}$ & \multirow{8}{*}{$\begin{array}{l}\infty \\
0 \\
0 \\
0\end{array}$} & $\begin{array}{c}1.7 \\
7\end{array}$ & \multirow{8}{*}{$\frac{n}{0}$} & $\begin{array}{c}0.2 \\
0\end{array}$ & \multirow{8}{*}{$\stackrel{5}{0}$} \\
\hline Northwest & 2.61 & $\begin{array}{l}14 . \\
87\end{array}$ & & $\begin{array}{c}2.5 \\
0\end{array}$ & & $\begin{array}{c}- \\
0.7 \\
8\end{array}$ & \\
\hline $\begin{array}{c}\text { North } \\
\text { Caucasian }\end{array}$ & 5.86 & $\begin{array}{l}26 . \\
33 \\
\end{array}$ & & $\begin{array}{c}0.6 \\
1\end{array}$ & & $\begin{array}{c}0.9 \\
2\end{array}$ & \\
\hline Ural & 6.97 & $\begin{array}{c}9.9 \\
3 \\
\end{array}$ & & $\begin{array}{c}0.9 \\
1\end{array}$ & & $\begin{array}{c}0.0 \\
6\end{array}$ & \\
\hline Youzhny & $\begin{array}{c}15.4 \\
7\end{array}$ & $\begin{array}{l}26 . \\
42\end{array}$ & & $\begin{array}{c}0.4 \\
5\end{array}$ & & $\begin{array}{c}0.6 \\
5\end{array}$ & \\
\hline Central & $\begin{array}{c}15.9 \\
5 \\
\end{array}$ & $\begin{array}{l}25 . \\
26 \\
\end{array}$ & & $\begin{array}{c}1.8 \\
2 \\
\end{array}$ & & $\begin{array}{c}1.1 \\
4 \\
\end{array}$ & \\
\hline Siberian & $\begin{array}{c}23.9 \\
0\end{array}$ & $\begin{array}{c}7.4 \\
8\end{array}$ & & $\begin{array}{c}0.4 \\
4\end{array}$ & & $\begin{array}{c}- \\
0.0 \\
3\end{array}$ & \\
\hline Volga & $\begin{array}{c}26.7 \\
7\end{array}$ & $\begin{array}{l}13 . \\
39\end{array}$ & & $\begin{array}{c}0.8 \\
7\end{array}$ & & $\begin{array}{c}0.4 \\
0\end{array}$ & \\
\hline
\end{tabular}

Assessment of regions and federal districts for a share of small farms allows claiming a lack of correlation between this indicator and gross output or gross output per 1 hectare of cultivated area of farms. This conclusion is also confirmed by correlation diagnostics.

Information on a share of territorial subjects of the Russian Federation in the gross output of agricultural industry and in the number of a livestock, their areas under crops and the number of small farms, allows us to carry out the analysis of an integrated indicator for distribution of federal subsidies (table 6).

The analysis and sorting of federal districts according to an indicator of distribution shows that this indicator does not correlate with efficiency of economic activity. So, an increase in an indicator of distribution does not reveal a profitability trend. Correlation between them only at the level of $12 \%$. Obviously, the chosen criterion of distribution of federal subsidies to regions for support of agricultural industry is optimum from a position of the maximum return from use of budgetary funds in the agrarian sector.
Table 5. Analysis of federal districts by share of farmers.

\begin{tabular}{|c|c|c|c|c|c|}
\hline \multirow[b]{2}{*}{$\begin{array}{l}\text { Federal } \\
\text { districts }\end{array}$} & \multirow{2}{*}{ 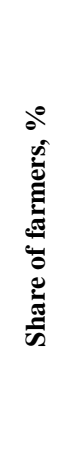 } & \multicolumn{2}{|c|}{ 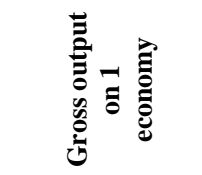 } & \multicolumn{2}{|c|}{ 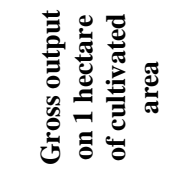 } \\
\hline & & 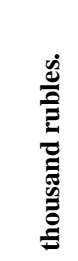 & 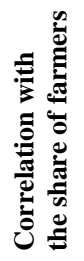 & 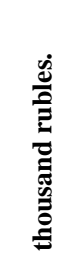 & $\begin{array}{l} \\
\end{array}$ \\
\hline Northwest & 4.1 & $\begin{array}{c}881.2 \\
2\end{array}$ & \multirow{8}{*}{$\stackrel{\overbrace{}}{0}$} & $\begin{array}{c}89.3 \\
1\end{array}$ & \multirow{8}{*}{$\stackrel{\infty}{0}$} \\
\hline Central & 7.9 & $\begin{array}{c}3647 . \\
41\end{array}$ & & $\begin{array}{c}47.7 \\
7\end{array}$ & \\
\hline Ural & 8.1 & $\begin{array}{c}3357 . \\
23\end{array}$ & & $\begin{array}{c}21.0 \\
8\end{array}$ & \\
\hline Volga & 12.4 & $\begin{array}{c}4449 . \\
21\end{array}$ & & $\begin{array}{c}28.7 \\
8\end{array}$ & \\
\hline Siberian & 12.9 & $\begin{array}{c}3040 . \\
61\end{array}$ & & $\begin{array}{c}20.3 \\
2\end{array}$ & \\
\hline Far East & 15.6 & $\begin{array}{c}2890 . \\
34\end{array}$ & & $\begin{array}{c}57.7 \\
5\end{array}$ & \\
\hline North Caucasian & 15.7 & $\begin{array}{c}1401 . \\
12\end{array}$ & & $\begin{array}{c}74.8 \\
6\end{array}$ & \\
\hline Youzhny & 20.0 & $\begin{array}{c}5165 . \\
01\end{array}$ & & $\begin{array}{c}58.6 \\
9\end{array}$ & \\
\hline
\end{tabular}

Table 6. The analysis of federal districts on an integrated indicator of distribution.

\begin{tabular}{|c|c|c|c|c|c|c|c|c|}
\hline \multirow[b]{2}{*}{$\begin{array}{l}\text { Federal } \\
\text { districts }\end{array}$} & \multicolumn{4}{|c|}{ Share, \% } & \multirow[b]{2}{*}{ 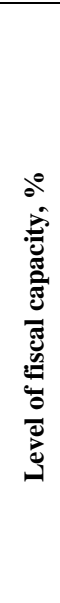 } & \multirow[b]{2}{*}{ 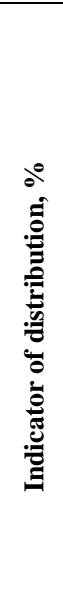 } & \multicolumn{2}{|c|}{$\begin{array}{c}\text { Profita } \\
\text { bility }\end{array}$} \\
\hline & 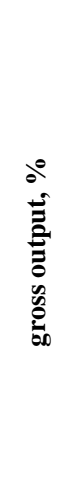 & 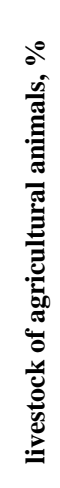 & 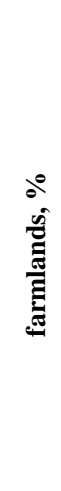 & 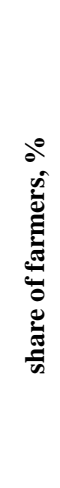 & & & $0^{\circ}$ & 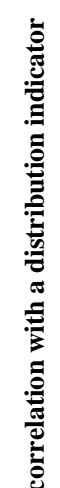 \\
\hline Northwest & $\begin{array}{c}4.6 \\
7\end{array}$ & $\begin{array}{c}3.4 \\
8\end{array}$ & $\begin{array}{c}2.6 \\
1\end{array}$ & $\begin{array}{c}4.1 \\
0\end{array}$ & $\begin{array}{c}95 . \\
0\end{array}$ & $\begin{array}{l}15 . \\
72\end{array}$ & $\begin{array}{c}- \\
4.4\end{array}$ & \multirow{8}{*}{$\begin{array}{c}0.1 \\
2\end{array}$} \\
\hline Ural & $\begin{array}{c}6.4 \\
1\end{array}$ & $\begin{array}{c}5.3 \\
4\end{array}$ & $\begin{array}{c}6.9 \\
7\end{array}$ & $\begin{array}{c}8.1 \\
0\end{array}$ & $\begin{array}{l}12 \\
8.0\end{array}$ & $\begin{array}{l}20 . \\
93\end{array}$ & $\begin{array}{c}5.0 \\
0\end{array}$ & \\
\hline Far East & $\begin{array}{c}3.0 \\
1\end{array}$ & $\begin{array}{c}2.1 \\
4\end{array}$ & $\begin{array}{c}2.4 \\
7\end{array}$ & $\begin{array}{l}15 . \\
60\end{array}$ & $\begin{array}{c}85 . \\
0\end{array}$ & $\begin{array}{l}27 . \\
40\end{array}$ & $\begin{array}{c}9.8 \\
0\end{array}$ & \\
\hline $\begin{array}{c}\text { North } \\
\text { Caucasian }\end{array}$ & $\begin{array}{c}8.1 \\
3\end{array}$ & $\begin{array}{l}11 . \\
79\end{array}$ & $\begin{array}{c}5.8 \\
6\end{array}$ & $\begin{array}{l}15 . \\
70\end{array}$ & $\begin{array}{c}67 . \\
0\end{array}$ & $\begin{array}{l}61 . \\
54\end{array}$ & $\begin{array}{l}12 . \\
60\end{array}$ & \\
\hline Central & $\begin{array}{l}24 . \\
84\end{array}$ & $\begin{array}{l}14 . \\
49\end{array}$ & $\begin{array}{l}0 \\
15 . \\
95\end{array}$ & $\begin{array}{c}7.9 \\
0\end{array}$ & $\begin{array}{c}88 . \\
0\end{array}$ & $\begin{array}{l}71 . \\
72\end{array}$ & $\begin{array}{c}7.5 \\
0\end{array}$ & \\
\hline Youzhny & $\begin{array}{l}15 . \\
40\end{array}$ & $\begin{array}{l}12 . \\
48\end{array}$ & $\begin{array}{l}15 . \\
47\end{array}$ & $\begin{array}{l}20 . \\
00\end{array}$ & $\begin{array}{c}78 . \\
0\end{array}$ & $\begin{array}{l}81 . \\
62\end{array}$ & $\begin{array}{c}9.9 \\
0\end{array}$ & \\
\hline Siberian & $\begin{array}{l}13 . \\
63\end{array}$ & $\begin{array}{l}21 . \\
32\end{array}$ & $\begin{array}{l}23 . \\
90\end{array}$ & $\begin{array}{l}12 . \\
90\end{array}$ & $\begin{array}{c}76 . \\
0\end{array}$ & $\begin{array}{l}94 . \\
83\end{array}$ & $\begin{array}{c}9.9 \\
0\end{array}$ & \\
\hline Volga & $\begin{array}{l}23 . \\
90\end{array}$ & $\begin{array}{l}28 . \\
95\end{array}$ & $\begin{array}{l}26 . \\
77\end{array}$ & $\begin{array}{l}12 . \\
40\end{array}$ & $\begin{array}{c}82 . \\
0\end{array}$ & $\begin{array}{l}112 \\
.09\end{array}$ & $\begin{array}{c}7.1 \\
0\end{array}$ & \\
\hline
\end{tabular}




\section{Conclusion}

Summarizing the conducted research, it is necessary to draw a number of important conclusions and proposals. They are connected with the fact that today, with formation of the state system of strategic economic planning in agricultural industry, the new mechanism of distribution of budget support to regions started. Its fundamental difference consists in an attempt to apply criterion of an agreement of budgetary appropriations with results of producers' activity. The choice of key indicators of distribution (shares of regions in production results on agricultural industry) was caused by aspiration of the accelerated solution of an issue of import substitution of food.

At the same time the prevalence of specific weight of the region in structure of any parameter does not demonstrate obtaining effect and especially efficiency yet, and, therefore, the role of budget support in formation of a certain share of the region is not obvious.

Many regions historically have a big share of farmlands and a big share of a livestock and thanks to that make a solid share of gross output. In the research, it is revealed that these regions even when using the old approach to distribution of federal support had its considerable specific weight in structure of the budgetary transfers. It demonstrates that subsidies do not define a share of regions in production, and, on the contrary, a products share, determines the size of subsidies.

From economic literature it is known that for assessment of results of agricultural producers' activity, development indicators are used. Examples of such indicators are volume of the produced and sold products per unit of area or per head of an agricultural animal, profit volume, also per unit of area or per head of an agricultural animal, profitability level.

The results received by the analysis demonstrate lack of harmony between the share indicators included in an official technique and the development indicators used in the research. Therefore, distribution of support by such technique will lead only to strengthening of differentiation of regions on the specific weight of state support, but will not promote growth of return from its use.

Requirements of the modern legislation and requirement of improving competitiveness of domestic producers in the internal and external markets dictate a need of development essentially of other mechanism of the distribution of federal support aimed at result and efficiency of the budgetary subsidizing in agricultural industry.

\section{References}

1. Yu.A. Akimova, S.A. Kochetkova, Basic Researches, 8 (2015)

2. G.V. Bespakhotny, Economics of Agricultural and Processing Enterprises, 1 (2016)
3. S.N. Babenkova, Agrarian and industrial complex: economy, management, 7 (2014)

4. L.Z. Aliyeva, S.J. Babayeva, S.A. Huseynova, O.A. Nasirova, F. Hasanzade, Bulgarian Journal of Agricultural Science, 25(2) (2019)

5. Yu. Rakhmatullin, Rural economics of Russia, 11 (2016)

6. A.A. Romanov, I.I. Bezayev, Bulletin of the Nizhny Novgorod state agricultural academy, 1 (2015)

7. I. Borodin, Rural economics of Russia, 10 (2014)

8. E.S. Alexandrov, Agrarian and industrial complexes: regions of Russia, 5 (2012)

9. I.V. Shavandina, A.D. Rein, Theory and practice of social development, 18 (2015)

10. A.I. Delekh, Bulletin of the Novosibirsk state agricultural university, 2 (2015)

11. N. Kuznetsov, I. Vorotnikov, A. Nayanov, Economic Annals-XXI, 1112 (2013)

12. M.R. Yashina, M.L. Bogapov, Financial analytics: problems and decisions, 2 (2016)

13. D.Yu. Samygin, N.G. Baryshnikov, L.A. Mizjurkina, Economy of Region, 15 (2019)

14. E. Volkova, K. Churilova, Rural economics of Russia, 1 (2017)

15. A.G. Glebova, N.V. Malysheva, Agrarian and land law, 6 (2015)

16. L.A. Eroshkina, European Social Science Journal, 12 (2015) 11

17.V. Mazloyev, A. Ktsoyev, Rural economics of Russia, 2 (2014)

18.S.V. Monakhov, E.N. Toropilova, E.A. Likhovtsova, Bulletin of the Saratov State Agrouniversity of N.I. Vavilov, 4 (2014)

19. D.Yu. Samygin, A.A. Kudryavtsev, Economic Policy, 13 (2018)

20. B. Vaznonis, G. Startiend, Economics \& Management, 14 (2009)

21. S.A. Wengle, Governance, 31(2) 2018 